Theological Research • volume 2 (20I4) NUMbeR I • P. 85-IO3 Dor: http://dx.doi.org/Io.15633/thr.680

Dariusz Kasprzak, O.F.M. Cap. The Pontifical University of John Paul II in Krakow, Poland

\title{
Monastic Exegesis and the Biblical Typology of Monasticism in the Patristic Period
}

\section{Abstract}

Monastic exegesis of the Bible in the Patristic period was characterized by ascetic pragmatism, reminiscence and meditation of the canonical text and at the same time its extra-verbal literal and spiritual interpretation. The consequence of such a manner of reading the text of the Bible was to acknowledge the monastic way of life as the royal path (via regia) and the monk as the one possessing certain spiritual knowledge and living faith. Systematic ignoring of the original Hebrew text by ancient monks, as well as by the Fathers of the Church, in using literal - spiritual and anagogical exegesis led to every biblical text being understood in a spiritual manner, i.e. as a text leading a monk to salvation. The biblical typologies of the monastic life also started to be derived from the theological rule of the Testaments. Those typologies resulted from the formerly adopted Christocentric theological premise assuming that the whole Bible tells about Christ and leads to Christ. They were the spiritual interpretation of the biblical text and were aimed at accounting for monasticism as the biblical form of life.

\section{KEYWORDS}

The Bible, monastic exegesis (literal - spiritual - anagogical), the royal path (via regia), biblical typology, the Patristic period. 


\section{INTRODUCTION}

Studying the monastic texts from the Patristic period one will notice a close connection between the original conventual movement and the Bible. This phenomenon was well analyzed and documented in western patristics. ${ }^{\mathrm{I}}$ My aim in this article is to familiarize the reader with the relationship between the Bible and patristic monasticism through synthesyzing the most important, in my view, theme of this issue, i.e. the description of monastic exegesis and, resulting from it, the biblical typologies of the monastic life.

\section{i. The Features of Monastic Exegesis in the Patristic Period}

García M. Colombás distinguished three characteristic features of the monastic manner of explaining the Bible in the Patristic period: ascetic pragmatism, the way based on the method of reminiscence/meditation of Holy Scripture, and the simultaneous literal and spiritual interpretation. Using the above-mentioned classification I am going to discuss the most significant features of monastic exegesis from the period of the Church Fathers.

\section{i.I. The Ascetic Pragmatism of Monastic Exegesis}

For the first monks, as well as for Origen, the Christian life consisted of meditating on the Holy Scriptures and introducing biblical rules

1 Cf. Écriture sainte et vie spirituelle, Paris I96o, pp. I28-278 (DSp, 4); C. Vagaggini (ed.), Problemi e orientamenti di spiritualità monastica, Roma I96r; G. M. Colombás, La Biblia en la espiritualidad del monacato primitivo, Yermo I (1963), pp. 3-20, I49-I70, 27I-286; 2 (I964), pp. 3-I4; II3-I29; L. Leloir, La lecture de l'Écriture selon les anciens Pères, Revue d'Ascétique et de Mystique 47 (1971), pp. I83-199; A. De Vogüé, Lectiones sanctas libenter audire, Benedictina 27 (1980), pp. II-26; M. I. Angelini, Il monaco e la parabola. Saggio sulla spiritualità monastica della lectio divina, Brescia I981; R. Kurek, La meditazione della Bibbia presso i monaci pacominiani, Rivista di Vita Spirituale 37 (1983), pp. 53-67; I. Gargano, L'apporto specifico del monachesimo nella lettura della Bibbia, in: La mediazione culturale del monachesimo, Parma 1987, pp. 86-95; A. de Vogüé, La lecture quotidienne dans les monastères (300-700), Collectanea Cisterciensia 5I (1989), pp. 240-25I. 
into everyday life. For that reason, in the ancient monastic community, the contents of the Bible were understood in a spiritual manner - as Christ's voice directed to the believer by the medium of the Church. The community of believers was acknowledged as the only possessor of God's Word. It was the Holy Spirit who had dictated the Holy Scriptures and who made it comprehensible. Hence, it was the Holy Spirit and not studying the Holy Scriptures itself that allowed for the deepest insight into the most essential meanings of the Bible. According to this ascetic code only the Holy Spirit allowed for understanding the spiritual sense of the Bible that brings life and sanctifies Christians. That is why monks did not believe solely in the academic understanding of God's Word as in ancient continuous biblical commentaries or the schola (i.e. philological - historical type of commentaries preserved on the margins of the manuscripts), but above all they tried to reach a state of pure heart. Through ascetic control over their passions, monks were meant to reach a purity of soul, in which state they could gain so called spiritual knowledge ${ }^{2}$ and follow the "royal way" (via regia) in their lives.

The second of the above mentioned concepts is especially essential for ancient and early medieval monasticism. According to Jean Leclercq OSB, the term "royal way" (via regia) in its original meaning signified a public road leading to the capital where the ruler was settled. The concept of a royal way was widespread in antiquity, especially in the ancient Egypt. The royal way constituted the opposite of the private way. It did not detour to villages or to wastelands. It was convenient, safe and led straight to the destination. Roads of this type were built of basalt sheets and maintained directly from the ruler's treasury. They were the pride of the ruler enabling efficient transportation, communication, and economic development. In its figurative sense, the term "royal way" signified the right, straight path, which was juxtaposed with unsure meandering paths. It was soon used to explain the way a believer had to follow in order to come to God (Philo of Alexandria, Clement of Alexandria). The theme of the royal way was described most comprehensibly by Origen in his Homilies on Numbers 12:4, in which he explained in an allegorical manner the text from Num. 2I:2I-24:

2 Cf. G. M. Colombàs, Bibbia e monachesimo, in: G. Rocca (ed.), Dizionario degli Istituti di Perfezione, vol. I, Roma 1974, p. I450. 
And the Scriptures tell another story. It says: "Moses sent" - or, as it says in other editions: "Israel sent" - "messengers to Sihon, the king of the Amorites," and stated in calm words: 'We will pass through your country; we will follow the road and we will not turn aside into any field or vineyard. We will not drink water from your well. We will travel along the royal way until we have passed through your territory.' But Sihon would not let Israel pass through his territory. He mustered his entire army and marched out into the desert against Israel. When he reached Jahaz, he fought with Israel. Israel, however, put him to the sword and took over his land. ${ }^{3}$

According to the Origen's allegories done for Num. 2I:2I - 24, 'Sihon' means "an infertile tree," "pride," "a tree full of pride and conceit," "the king of the Amorites" - "the one leading towards bitterness" or "the one who speaks;" "in the spiritual sense Sihon symbolizes the devil - because the devil is conceited and infertile;" "the prince of this world;" "any king of pagans;" "the prince of sinners;" "the prince of sins;" "the prince of evil and wickedness." Christ, ${ }^{4}$ on the other hand, is called "our prince" or "the prince of virtues," and the expression "we are coming to Jahaz ("ueniamus in Issaar')" means "the coming out of commandments" - "fulfilling commandments," "keeping the commandments and orders of our Lord Jesus Christ." 5

Referring to the quoted text, Origen also provided a spiritual explanation of the "royal way" figuratively understood as the safe and enlightened way a Christian follows on his path to God. ${ }^{6}$

Origen's description was repeated by John Cassian (The Conversations of the Fathers 24:24-26), and then by Benedict of Nursia and Rabanus Maurus. Due to that fact the concept of the "via regia" became synonymous for the monastic life in the Middle Ages. ${ }^{7}$ The ascetic pragmatism of the early Egyptian monks, ${ }^{8}$ depicted by Evagrius Ponticus and John

3 Origène, Homélies sur les Nombres 12:4:I, ed. L. Doutreleau, Paris 1999, pp. Ioo, IO2 (SCh 442), own translation.

4 Origène, Homélies sur les Nombres 12:4:3, p. I04 (own translation).

5 Origène, Homélies sur les Nombres 12:4:7, p. II2 (own translation).

6 Origène, Homélies sur les Nombres I2:4:5-7, pp. Io6-II2 (own translation).

7 J. Leclercq, Cultura umanistica e desiderio di Dio. Studio sulla letteratura monastica del Medioevo, Milano 2002, p. I35-138.

8 Cf. J. C. Guy, Écriture sainte et vie spirituelle. 4. Le monachisme, Paris I96o, pp. 159-164 (DSp, 4). 
Cassian, ${ }^{9}$ was later propagated by the Cappadocian Fathers, and in the west by Benedict of Nursia ${ }^{\text {Io }}$ and Saint Gregory the Great. ${ }^{\text {II }}$

\section{i.2. Meditation}

The second feature of biblical monastic exegesis was meditation on the text of the Holy Scriptures. ${ }^{\mathrm{I2}}$ The ancient monastic founders makers such as Saint Anthony the Great, Saint Pachomius the Great, Saint Basil the Great or Saint Benedict of Nursia, recommended the Bible as a basic textbook to their monks. The monks were supposed to read, listen to, rewrite, and study the Bible. They were to learn it by heart, and interpret it. One can find examples of the approach to the Bible as a textbook of the monk's life in source texts from early monasticism. ${ }^{13}$ Anthony is depicted by Athanasius as a master of listening to and reflecting upon God's Word and using it in his own life: from the ascetic conversion, ${ }^{\mathrm{I}}$ through the fight against the devil, ${ }^{15}$ and undertaken ascetic exercises ${ }^{16}$ as the one singing psalms during the 20 year period of seclusion ${ }^{17}$ and the one who is the man of God. ${ }^{18}$ Pachomius put the monks under the obligation to learn to read in order for them to be able to familiarize themselves with the text of the Bible and to learn it by heart. ${ }^{19}$

9 Cf. J. Kirchmeyer, Écriture sainte et vie spirituelle. $4^{\circ}$ Évagre et l'antirrbétique. $5^{\circ}$ Saint Nil, Paris 1960, pp. 164-167 (DSp, 4).

10 Cf. J. Gaillard, Écriture sainte et vie spirituelle. 6o Saint Benoit, Paris I96o, pp. 167-169 (DSp, 4).

11 Cf. B. De Vregille, Écriture sainte et vie spirituelle. B. Du $6^{\text {eau rze siecle. }}$. . Saint Grégoire le Grand, Paris i96o, pp. I69-176 (DSp, 4).

12 Cf. E. von Severus, A. Solignac, Méditation. I. De L'Écriture aux auteurs médiévaux, Paris 1980, pp. 907-914 (DSp, Io).

13 Cf. G. M. Colombàs, Bibbia e monachesimo..., pp. I448.

14 Athanasius of Alexandria, The Life of Saint Anthony 2-3, ed. G. J. M. Bartelink, Paris 1994, pp. 132-138(SCh 400).

15 Athanasius of Alexandria, The Life of Saint Anthony 6-7, pp. 146-I56.

16 Athanasius of Alexandria, The Life of Saint Anthony 8-9, pp. 156-162.

17 Athanasius of Alexandria, The Life of Saint Anthony 13, pp. I68-I72.

18 Athanasius of Alexandria, The Life of Saint Anthony 14, pp. 172-I74; Cf. Ibid, pp. 45-51; 66-67; 68-70; 71-79; 84; 88-89.

19 Pachomius, Precepts, I39-I40: „139. A noviciate who comes to a monastery is first instructed regarding what rules he is supposed to obey. When, having been instructed, he agrees to everything, he will be given twenty psalms or two epistles or another part of the Bible to learn. If he cannot read, he will go at one o'clock [about six o'clock], three o'clock [about nine o'clock] and six o'clock [about twelve o'clock] to the 
A similar approach to the biblical text may be observed in the works of Theodore of Alexandria or Orsisius, the subsequent great Pachomian monks. In those texts, the coherency of the quoted biblical sentences exceeds all expectations and originates from their absolute need to be faithful to God's Word. ${ }^{20}$ A. Veilleux managed to gather 2500 biblical verses from the works of the first Pachomian monks. According to his view, it proves that those who learned the Bible by heart and followed its instructions possessed astonishing knowledge of the Bible. The same researcher showed that knowledge of the Bible among those monks was also the best means against heresy, at least until the emergence of the Monophysites, and that no proof of any contact between the Pachomian communities and the representatives of the gnosis from Nag Hammadi exists. ${ }^{2 \pi}$ For the Egyptian anachoretes and coenobites the meditated Bible became a specific teacher of morality (magistra morum). ${ }^{22}$ Similarly, for the patriarch of the western monks, Benedict of Nursia, the Bible, and especially the psalms, made up the main part of the Divine Office and became the subject of the monastic readings (lectio), ${ }^{23}$ to which each monk should devote many hours every day. ${ }^{24}$

What is striking about the meditation on the Bible by the first generations of monks is the practice of learning whole parts of the Holy Scriptures by heart in order for the memory to become the book

one who can teach him and who was designated to teach him, he will stand in front of him and learn best he can and he will thank him. Then, elements, syllables, words and nouns will be written to him, and if he does not want to learn, he should be even forced to learn to read. I40. There will be nobody in the monastery who cannot read and who does not know some part of the Holy Scriptures, or at least the New Testament and the Psalterium by heart": Pachomiana Latina, Kraków I996, p. I54 (Źródła Monastyczne, II) own translation.

20 Cf. V. Desprez, Cenobityzm pachomiañski, Kraków i996, p. 8I (Źródła Monastyczne, II).

21 Cf. A. Veilleux, Holy Scripture in Pachomians Koinonia, Studia Monastica ro (1974), pp. I43-I53; Id., Monachisme et gnose. I. Le cénobitisme pachômien et la bibliothèque copte de Nag Hammadi, Collectanea Cisterciensia 46 (1985), pp. 239-258.

22 Cf. J. C. Guy, Écriture sainte et vie spirituelle. 4. Le monachisme..., I6r.

23 Reguta śrw. Benedykta, przekł. T. M. Dąbek, 8-18, Kraków 2006, pp. 418-433 (Źródła Monastyczne, 40), Cf. Ch. Dumont, Pour un peu démythiser la "lectio" des anciens moines, Collectanea Cisterciensia 32 (1970), pp. 217-230; L. Leloir, La lecture de l'ecriture selon les ancien péres, Revue d'Ascétique et de Mystique 47 (1971), pp. 54-66, M. I. Angelini, Il monaco e la parabola. Saggio sulla spiritualità monastica della lectio divina.

${ }^{24}$ Reguta św. Benedykta, I6, p. 429; Reguta śrw. Benedykta, 47, p. 467. 
(Anthony the Great), ${ }^{25}$ to be able to pray using the memorized text (Pachomius), ${ }^{26}$ to meditate on it, ${ }^{27}$ and to acquire faith ${ }^{28}$ (Orsisius). The $\mu \varepsilon \lambda \dot{\eta} \eta$ / meditari-meditatio practise was already known in some philosophical schools however the first Christian monks borrowed it from the Judeo-Christian tradition. ${ }^{29}$ The practice of reading aloud, reciting, and learning specific biblical texts by heart, which were then meditated upon, was passed on by the original anachorites and coenobites to the subsequent generations of monks..$^{\circ}$ With time, meditatio became the classical spiritual instruction of Christian monasticism, in the Middle Ages known as ruminari - ruminatio or masticatio..$^{35}$ However, in the fifteenth century it was forced out by mental meditation propagated by devotio moderna..$^{32}$

\section{i.3. Simultaneous Literal and Spiritual Interpretation}

The most fundamental text of the Old Testament analyzed and commented on by the eastern monks was the Septuagint, less so the translations of Symmachus, Theodosianus, or Aquila. For the western monks,

25 Athanasius of Alexandria, The Life of Saint Anthony 3:6: „And he listened so attentively when the Scriptures were read out not to let any word fall to the ground and so his memory sufficed him": I38 (own translation).

26 Pachomius, Precepts $\mathrm{I} 3:$,...everybody according to the order in which they sit or stand are supposed to repeat what they were instructed to learn by heart": Pachomiana Latina, I3r; Ibid. 49: „He will then be taught the Lord's Prayer and as many Psalms as he can remember": Pachomiana Latina, 137 (own translation); Cf. Ibid I22; I39; I40.

27 The Book of Orsisius, 51: „We shall care about reading and learning the Scriptures and about constant meditating upon them... These are the words, which lead us to the eternal life. They were given to us by the Father who instructed us to meditate upon them constantly": Pachomiana Latina, 265 (own translation).

28 The Book of Orsisius, 52: „Behold the numerous examples of the God's Word that encourage us to contemplate the Holy Scriptures so that we acquire by means of faith what we pronounce with our mouth": Pachomiana Latina, 265 (own translation).

29 Cf. G. M. Colombàs, Bibbia e monachesimo..., p. I449.

30 Cf. H. Bacht, „Meditation” in den ältesten Mönchquellen, Geist und Leben Zeitschrift für Askese und Mystik 28 (1955), pp. 36o-373; R. Kurek, Biblijna orientacja medytacji pachominskiej, Vox Patrum 7 (I98I), pp. 247-254.

31 Cf. E. Ruppert, Meditatio-Ruminatio. Une méthode traditionelle de méditation, Collectanea Cisterciensia 39 (1977), pp. 8I-93; J. Leclercq, Cultura umanistica e desiderio di Dio..., pp. II9-I39.

32 Cf. M. Goossens, Méditation. II. Les méthodes dans la spiritualité chrétienne, Paris 1980, pp. 914-919 (DSp, го). 
on the other hand, the text of the Old Testament was read in its Veteres latinae versions, from the fifth century it was gradually forced out by Jerome's Vulgate. The ancient monks then only used the Greek and Latin translations, and similar to most of the Church Fathers, they did not refer back to the Hebrew original of the Old Testament, which, as a rule, they ignored. 33

Monastic exegesis of the Bible in the Patristic period was a simultaneous literal and spiritual interpretation of the text of Holy Scripture. The literal interpretation focused especially on the meaning of individual biblical terms. For that reason the norms of ancient grammar were used in the monastic interpretation of the Bible since it helped to memorize the recited text on the basis of the mnemonic techniques. Through continuous reference to the rule of reminiscence, the ancient monks used the biblical motifs and scenes of one book to refer to the motifs and scenes existing in other books. Under the influence of Philo of Alexandria, and most of all of Origen, the first monks tried to differentiate in their interpretations between typology and allegory. At the same time they highlighted the historicity of the events described in the Old Testament, they based their interpretation on the rule of correlation and complementation of the Old and New Testament, and in the eschatological interpretation key, they tried to decode types and antitypes, figures and their realizations..$^{34}$

Alongside literal interpretation, the monks explained each biblical text in a spiritual manner. The belief that lay at the foundation of the spiritual interpretation was that the whole Bible constitutes knowledge about salvation. This knowledge concerns the meaning of each individual word as well as the message included in whole books. The soteriological meaning of the Bible is directed to each individual reading the biblical text by God, who is the proper author of the Holy Scriptures. God's aim is to save each individual. Such an interpretation of the Holy Scriptures had an always present and personal value for each monk who read the Bible. ${ }^{35}$

33 Cf. J. Daniélou, Écriture sainte et vie spirituelle. II. Écriture et vie spirituelle dans la Tradition. A. Époque patristique (2 (2-6esiecle). . Exégèse et typologie patristiques, p. 135 (DSp, 4).

34 Cf. J. Daniélou, Exégèse et typologie patristiques..., pp. I33-135; Idem, Origène comme exégète de la Bible, Studia Patristica I (I957), pp. 280-29o; M. I. Angelini, Il monaco e la parabola. Saggio sulla spiritualità monastica della lectio divina.

35 Cf. G. M. Colombàs, Bibbia e monachesimo..., I45o; I. Gargano, L'apporto specifico del monachesimo nella lettura della Bibbia, in: La mediazione culturale del monachesimo, 


\section{The Biblical Typology of the Monastic Life}

The theological rule of the compatibility of the Old and New Testament, accepted by patristic exegesis allowed the Christians of the first centuries to see the close connection between the persons, events, and institutions of the first and second covenant of God with people. This compatibility did not concern details but the most significant element and only that kind of compatibility, as analogical adequateness, was highlighted by proponents of patristic exegesis. The most basic theological assumption of the rule of compatibility of both Testaments was the belief that the nature of God's actions never changed in the course of the history of salvation. Already in the Old Testament one can find the compatibility of earlier and later events (e.g. the story of leaving slavery in Egypt was read out in Isa 51:10; 52:7-I2 as a model of ultimate salvation of Israel). This compatibility of the biblical message was used also in Christianity. Hence, when an earlier tradition or person was interpreted as an expression of a new saving act on the part of God, that kind of event was called in patristic exegesis a type of new real-

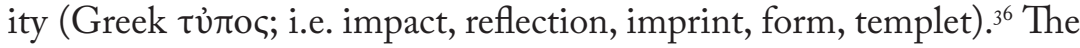
former reflections are the types and the foretold ones are antitypes. The typological sense referred more to people, places, and events than to words only. It circumscribed the more profound meaning of things described in the Bible seen as anticipatory reflections of the earlier acts being part of God's saving actions. ${ }^{37}$

Parma I987, pp. 86-95; A. de Vogüé, La lecture quotidienne dans les monastères (300-700), Collectanea Cisterciensia 5I (I989), pp. 240-25I.

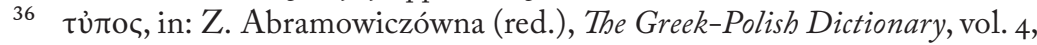
Warszawa 1965, pp. 374-375, lists I9 meanings of this term: r. blow, knock; 2. an imprint of a seal, an impress of a coin, imprint, reflection, a place with an imprint, reflections, images; 3. casting mould, matrix, stamp used for making coins; 4. an engraved sign, an eroded sign; 5 . bas-relief, relief; 6. sculpted figure, statue, statua, painted figures of the frontage, engraved picture (LXX); 7. an exact print, picture, about children looking like their parents; 8. shape, form; 9. a form of expression, style; IO. exemplar, model; II. character, type, kind; I2. type of disease, type of fever; I3. general feature, vague appearance, unclear; I4. outline, sketch, general rule, guideline; i5. role model, norm; r6. general instruction, disposition; I7. sketch of work; I8. text; I9. statement of claim.

37 R. E. Brown, Hermeneutyka biblijna, in: R. E. Brown, J. A. Fitzmyer, R. E. Murphy (red.) Katolicki komentarz biblijny, przekł. K. Bardski, Warszawa 20oI, p. I80I. 
Whether a person, place, or event will be a type of something else was only possible to ascertain a posteriori (e.g. Adam as a type of Christ; Melchizedek as a type of Christ; the events concerning Israel that took place in the desert are types in relation to Christians; Christ gives a sense to the Old Testament as its fulfillment; the patriarch Jacob is a type of the Christian people, and this same crippled patriarch is additionally a personage in the Church - the Church in which sinners are present - "the cripples;" Sabbath is the type of the future kingdom of the saints, etc.)..$^{38}$

The biblical typology used in patristic exegesis as a specific hermeneutic technique ${ }^{39}$ according to Jean Daniélou employed three fundamental theological criteria, which differentiated between typology and allegory. The first one was using a given typological parallel in the earlier theological tradition. Hence, when a given figurative theme from the Old Testament was already used by the Fathers of the Church, it showed that it could actually be found in the New Testament. The second criterion of the authentic typology referred to the literal sense. Since the exegetes of the Patristic period ignored the Hebrew text of the Old Testament, typological parallels between the Greek Septuagint text and the original Greek texts of the New Testament were used. That second criterion is the most ambiguous for contemporary historical-critical exegesis. Finally, the third criterion of authentic typology was not comparing the details of fragments of the Old Testament with their New Testament equivalents, but rather whole complete stories or saving realities from the Old Testament. ${ }^{40}$

As Krzysztof Bardski ${ }^{4 \mathrm{I}}$ points out, from the point of view of contemporary biblical hermeneutics, the patristic biblical typology appertains to the traditional spiritual sense, which is currently classified as an extra-verbal sense ${ }^{42}$ that is fundamentally different from the literal

38 A. Di Berardino, Tipologia, in: Nuovo Dizionario Patristico e di Antichità Cristiane, vol. 3 (P-Z), Genova-Milano 2008², p. 5369-5370.

39 J. N. Guinot, La typologie comme technique herméneutique: figures de l'Ancien Testament chez les Pères, Strasbourg I989, pp. I-34 (Cahiers de Biblia Patristica, 2).

40 Cf. J. Daniélou, Exégèse et typologie patristiques..., pp. I33-136.

41 Cf. K. Bardski, Stowo oczyma Gotębicy. Metodologia symboliczno-alegorycznej interpretacji Biblii oraz jej teologiczne i duszpasterskie zastosowanie, Warszawa 2007, pp. 50-55.

42 The extra-verbal sense: it is an ever and anone new interpretation of the sense of the Bible, according to the statement of Gregory the Great: "God's Word grows together with the reader" (Hom. in Ezech. I.7.8); the evolution of the extra-verbal 
sense. ${ }^{43}$ According to the authors of the Jerome Biblical Commentary, the extra-verbal sense, typical for patristic and medieval hermeneutics and for some modern research methods (rhetorical, narrative, phenomenological, and canonical critique), suggests a semantic superstructure which is characteristic for the interpretations of the senses traditionally referred to as spiritual. ${ }^{44}$

Raymond E. Brown claims that, from the point of view of exegesis and hermeneutics of the historical-critical type, the weakest side of patristic and medieval exegesis, which aim was to reach the extra-verbal sense, was the issue of choosing the appropriate hermeneutical criteria. This statement refers mostly to biblical patristic typology. The classical criteria used for recognizing Revelation since Christian antiquity (the unanimous opinion of the Fathers of the Church, the constant liturgical tradition, the Church's teaching) refers to the following: God's intention, God's plan, the constant model of vow and its fulfillment, that is proving that the typology sense results from the Christian faith that the God of Revelation always acts consequently, and not accidentally; also that God's help ${ }^{45}$ is indispensable to be able to ascertain with certain confidence that there exists a connection between the type and antitype. For that reason the conclusion drawn by Krzysztof Bardski that the extra-verbal interpretation of the biblical text is in contempo-

interpretation has not the character of progress but rather is characterized by a specific changeability of certain models of classical character; at the extra-verbal level, creativity is on the part of the reader to a large extent; the extra-verbal sense is in its nature a subjective creation of the receiver of the biblical text; it is unnecessary but can be useful; it has not got the cognitive character in the relation to the text (thus its low value for so called scripturistic argumentation in theology); it requires a holistic view of the text and is created during the second or third reading or after finishing reading, it is a specific "radiation" of the text on the awareness of the reader. It is a typical sense for the patristic and early medieval interpretation of the Bible. Cf. K. Bardski, Stowo oczyma Gotębicy..., pp. 50-55.

43 Sense which was directly intended by the human author of the Bible and is carried by human words which were written down. It can be divided into literal and allegorical sense. The verbatim sense: it is only one, invariable, the author of the utterance is its creator, it is intersubjectivly verifiable, it is necessary, it has a cognitive character in relation to the text, it is gradually discovered in the process of reading and has got a linear character. This type of sense if the main object of interest in the contemporary historical-critical exegesis. Cf. R. E. Brown, Hermeneutyka biblijna..., p. I789; K. Bardski, Stowo oczyma Gotębicy..., pp. 50-55.

44 R. E. Brown, Hermeneutyka biblijna..., pp. I796-I8Io.
45 R. E. Brown, Hermeneutyka biblijna ..., pp. I80I-I802. 
rary historical-critical exegesis more of an esthetic than scientific value and it can be used for depicting theological truths. It is also useful in the pastoral sense and can be used for deepening relations with God on the basis of the meditated text of the Holy Scriptures. ${ }^{46}$

Regardless of critical evaluations of the traditional spiritual sense by contemporary biblical hermeneutics, the extra-verbal interpretation of the Bible constitutes one of the most substantial elements of the Tradition of the Church. What is more, some documents of the Magisterium ecclesiae point at the essential significance of the extra-verbal interpretation of the Bible in the life of the Church. ${ }^{47}$ It is a historical fact that the typological interpretation of the Holy Scriptures found a very practical use in the monastic interpretation of the canonical text. The first monks found in the Bible descriptions of many characters that were acknowledged by subsequent monastic commentators as biblical role models for the monastic life. G. M. Colombas distinguished seven biblical characters that with time became the canon of the biblical typology of the monastic life. These are: Adam, Elijah, Elisha and the prophet's sons, John the Baptist, Jesus, the Apostles, and the first Church community in Jerusalem..$^{8}$

Adam, before falling into sin. The first man, before he sinned, constituted a model of the monastic life since he lived in paradise - the place abundant in happiness, he lived an angelic life, he was clothed in God's grace and had amicable dialogue with God ( $C f$. John Chrysostom, Homilies on the Gospel of Matthew 68:3). ${ }^{49}$ For that reason Adam dwelling in paradise in the state of innocence became for the monks an image of a perfect contemplating person (Dorotheus of Gaza, Various Teachings r:I). The proof of the paradisal state from before Adam's sin was friendship between the Man and animals. It resulted from the belief that God dwells in a sinless person and for that reason all animals and elemental powers obey him (Cf. Cyril of Scythopolis, The Life of Saint Euthymius 13). For that reason showing the topos of paradise regained ( $C f$. Iz Ir:6-8; 65:25) was a common hagigraphic mo-

46 K. Bardski, Stowo oczyma Gotębicy..., pp. I06-I20.

47 Cf. Catechism of the Catholic Church nr Io9; nr II5-Ir9; Pontifical Biblical Commission, The Interpretation of the Bible in the Church (April I5, I993) II B2; Pope Benedict XVI, Verbum Domini nr $37-38$ and nr 48.

48 Cf. G. M. Colombàs, Bibbia e monachesimo..., pp. I452-I455.

49 Cf. G. M. Colombàs, Bibbia e monachesimo..., p. I452. 
tif in the depictions of intimateness of the monks and wild animals: Anthony the Hermit reprimanding animals that were destroying his crops (Cf. Athanasius of Alexandria, The Life of Saint Anthony 50); an anchorite feeding on his lap bread and chickpeas to a lion ( $C f$. John Moschus, The Spiritual Meadow I8, 58, I0I, I25, 18I).50

Elijah. He was a spiritual type of monk since as God's prophet he stayed in the desert ( $C f$. Jerome of Stridon, Epistle 63:5) surrounded by an aura of mysteriousness, he became a role model for a perfect life (Cf. John Cassian, Institutions r:2) as a spiritual forerunner and master of future monks ( $C f$. Ambrose of Milan, Epistle 63:82). Elijah, hidden in the desert or withdrawing to Mount Carmel, constituted a model of God's man separating himself from the world; living his whole life in purity he was a model example of this virtue for others (reference to the topos of "heavenly life"). He was also a model of a fasting man, living in silence and rigourism (reference to the topos of apathei), of the contemplative and mystical life ( $C f$. Athanasius of Alexandria, The Life of Saint Anthony 7; John Cassian, Conferences I4:4). The reference to the monastic life as the "prophetic life" ${ }^{{ }_{\mathrm{II}}}$ was later derived from the typology of Elijah.

Elisha and the sons of the prophets. Elisha was presented as the spiritual father of the monks because he was such a father to the sons of the prophets. Whereas the Old Testament sons or disciples of the prophets were acknowledged as the monks of the first covenant because they escaped from the cities, lived in poor houses along the river Jordan and ate simple food ( $C f$. Jerome of Stridon, Epistle I25:7)..$^{22}$

John the Baptist was presented as a type of a perfect monk since he spent his whole life in the desert (Cf. John Chrysostom, Homilies on Matthew Io:4) and showed exceptional rigorism in renouncing

50 P. Miquel, Znaczenie i motywacje monastycyzmu, in: Aimé Solignac et al.; Monastycyzm. Historia i duchowość, przekł. D. Stanicka-Apostoł, Kraków 2002, p. 82-83.

51 Cf. J. Leclerq, La vie parfaite, Paris 1948, pp. 57-8r; G. Bardy, Élie le prophète, Bruges-Paris 1956 (Études Carmélitaines, 2); C. Peters, Elie et l'idéal monastique, pp. 567-572 (DSp, 4); G. M. Colombàs, Bibbia e monachesimo..., pp. I452-I453; Le saint prophète Elie d'après les Péres de l'Église, Coll. Spiritualité Orientale 53, Bellefontaine I993; É. Poirot, Elie, archétype du moine. Pour un ressourcement prophétique de la vie monastique, Bellefontaine 1995 (Coll. Spiritualité Orientale, 65).

52 Cf. G. M. Colombàs, Bibbia e monachesimo..., p. I453; Le saint prophète Elisée d'après les Pères de l'Eglise, Bellefontaine 1993 (Coll. Spiritualité Orientale, 59); É. Poirot, Les prophètes Élie et Élisée dans la littérature chrétienne ancienne, Bellefontaine I997. 
mundane goods. He experienced the austerity of life and solitude in the desert and he constantly waited for Christ (Cf. Jerome of Stridon, Homilies on the Gospel of John). The figure of John the Baptist was always considered to be a role model of virginity, love of solitude, and renouncement of food and clothes and hence in the Middle Ages he became the topos of monastic hagiography ( $C f$. Peter Damian, Sermo 23). 53

Jesus. The life of the monks, similarly to the lives of all Christians, entails following Christ - sequela Christi (Athanasius of Alexandria, The Life of Saint Anthony 2; Sancti Pachomii vita prima 24; Sancti Pachomii vita secunda 21; The Book of Orsisius 6; Aphrahat of Syria, Demonstratio 6. De monachis I; Historia monachorum in Aegypto 4-5; Basil the Great, Epistle 2:I). Jesus always constitutes the first and most perfect model of Christian life. The monks pointed especially to those examples from the life of Jesus which were fundamental for living the monastic life: fasting and fighting the demon in the desert (Matt. 4:I-II), prayer in solitude on the mountain (Matt. 14:23), renouncement of all mundane property (Matt 8:20; 2 Cor. 8:9), humility and service to his neighbours (Phil. 2:7).54

The Apostles. The monks endeavored to follow the example of the life of the apostles and referred to their life as apostolic, hence, alongside the prophets of the Old Testament, the apostles of the New Testament were considered to be the founders of the monastic movement. This typology was especially developed in the Middle Ages when the monastic life was propagated as the actualization of the apostolic life: the monks, similarly to the apostles, abandoned everything, gathered around the Savior and lived in his school, were steadfast in prayer, thanksgiving and perfect brotherly love (Cf. Bernard of Clairvaux, De diversis sermo 22:2).55

The first community of the Church in Jerusalem. Deriving the genesis and manner of the monastic life from the idealizing message of Luke the Acts on the first Church community in Jerusalem

53 Cf. G. M. Colombàs, Bibbia e monachesimo..., p. I454; J. Steinmann, St JeanBaptiste et la spiritualité du désert, Paris 1955; G. Penco, S. Giovanni Battista nel ricordo del monachesimo medievale, Studia Monastica 3 (196I), pp. 7-32.

54 Cf. N. Schedl, Jesus Christus, Sein Bild bei den Mönchen der Sketis, Wien 1943;

G. M. Colombàs, Bibbia e monachesimo..., p. I454.

55 Cf. G. M. Colombàs, Bibbia e monachesimo..., p. I455. 
first appeared in the Coptic biographies of Pachomius. In that hagiographic understanding the coenobite life was supposed to reflect the lifestyle of a perfect Christian community from Acts 2:42-47; 4:32-34. In the monastic texts of Basil the Great and Augustine of Hippo one will notice a longing for this ideal Christian community and for the model of relationships between the believers in that community. For that reason John Cassian (Institutions 2:5; Conferences 18:4-5) tried to prove that the community of Jerusalem should constitute the real model to follow for subsequent Christian communities, and especially for the coenobitic communities. G. M. Colombás, pointing out historic falsehoods in a thesis put forward in such a way, emphasizes that it is however true from the spiritual point of view. "Even if there is nothing that could allow to assume that the first Coptic monasteries were created due to continuous tradition dating back to the apostolic Church, it is certain that the Christian coenobitism appeared due to apostolic teachings and the model of the first community in Jerusalem." ${ }^{6}$

It appears that the biblical typology of the monastic life described here is helpful in ascertaining what a monk is and what the monastic manner of interpreting the evangelical life is. Pierre Miquel, trying to provide the meaning of the definition of a monk in the Christian tradition of the first millennium came to the conclusion that the terms monachos and monachus mean: (I) the one who lives alone (eremite, anchorite); (2) the one who resigned from family and marriage and its benefits; (3) the one who lives in unity with others (coenobite); the one who is homogene ("simple"). While the first meaning is acknowledged in the monastic tradition, the second one is colloquial (e.g. the Meletian monks, the Egyptian "country monks" or, so called remnuôth in the Jerome's description). The third interpretation of the term has its grounds in two biblical texts (Ps I32 (I3I): I - brothers living in unity; Acts 4:32 - the Luke's ideal of the community according to one heart and one soul). Hence, in the ancient monasticism understanding, a monk would be the one who is "united in oneself" and accomplishes ones "unity with God." It is not, however, an accurate definition of

56 G. M. Colombàs, Bibbia e monachesimo..., p. I455. Por. L. Th. Lefort, Les vies coptes de saint Pachôme et de ses premiers successeurs, Leuven I943; J. Gribomont, Obéissance et Evangile selon saint Basile le Grand, Supplément de „La Vie Spirituelle” VI (I952), pp. 192-195; J. Gribomont, Les Règles morales de saint Basile et le Nouveau Testament, Studia Patristica 2 (1957), pp. 416-426. 
monasticism. That is why P. Miquel, referring to the concept of the archetype used in religious studies as to the oldest and deepest structure of different demonstrations of sacrum, defines the idea of ancient monasticism by listing nine archetypes of the monasticism of antiquity: (I) following Christ; (2) longing for the original Christian community; (3) replacement or preparing for martyrdom; (4) fight against demons; (5) ascetic migration and spiritual Exodus; (6) emulating the life of angels; (7) return to Adam's innocence; (8) vigilant waiting for parousia; (9) the true philosophy. ${ }^{57}$

The archetypes listed above, being also the ideals motivating the monks of antiquity to start this type of life and to adhere to it, had their justification in the typological and anagogical interpretation of the Bible. They resulted from the spiritual and Christological interpretation of the canonical text. Thus, attempts at proving the legitimacy of the monastic life based on the biblical typologies were a way of showing that monasticism constitutes a form of biblical life. It appears that due to the spiritual applicability of the discussed typologies, they were commonly used in the ancient and early medieval monasticism.

\section{Conclusion}

Monastic exegesis of the Bible in the Patristic period was characterized by ascetic pragmatism, reminiscence, and meditation on canonical texts and at the same time its extra-verbal literal and spiritual interpretation. The consequence of such manner of reading the text of the Bible was acknowledging the monastic way of life as the royal path (via regia) and the monk as the one possessing certain spiritual knowledge and living faith. The systematic ignoring of the original Hebrew text by the ancient monks, as well as by the Fathers of the Church, in using a literal - spiritual and anagogical exegesis led to every biblical text being understood in a spiritual manner, i.e. as a text leading a monk to salvation. The biblical typologies of the monastic life also started to be derived from the theological rule of the Testaments. Those typologies resulted from formerly adopted Christocentric theological premise assuming that the whole Bible tells about Christ and leads to Christ. They were

57 Cf. P. Miquel, Znaczenie i motywacje monastycyzmu..., pp. 67-89. 
the spiritual interpretation of the biblical text and were aimed at accounting for monasticism as the biblical form of life.

The discussed biblical typologies, in the context of contemporary biblical exegesis of the historical - critical stream, constitutes an example of the extra-verbal interpretation of the canonical text and as such they are of more esthetic than scientific value. However, the biblical typologies of the monastic life constitute a vital part of the extra-verbal interpretation of the Bible, which is one of the most permanent elements of the Church Tradition. The latest documents of the Magisterium point out the fundamental importance of the extra-verbal interpretation of the Bible in the life of the Church. For that reason the discussed typologies can still be used to exemplify theological truths. They are also useful in pastoral and formational contexts and in deepening one's relations with God on the basis of the text of the Holy Scriptures.

\section{BiBLIOGRAPHY}

Abramowiczówna Z. (red.), The Greek-Polish Dictionary, vol. 4, Warszawa 1965.

Angelini M. I., Il monaco e la parabola. Saggio sulla spiritualità monastica della lectio divina, Brescia I981.

Athanasius of Alexandria, The Life of Saint Anthony 2-3, ed. G. J. M. Bartelink, Paris 1994 (SCh, 400).

Bacht H., „Meditation” in den ältesten Mönchquellen, Geist und Leben Zeitschrift für Askese und Mystik 28 (1955), pp. 360-373.

Bardski K., Stowo oczyma Gotębicy. Metodologia symboliczno-alegorycznej interpretacji Biblii oraz jej teologiczne i duszpasterskie zastosowanie, Warszawa 2007.

Bardy G., Élie le prophète, Bruges-Paris 1956 (Études Carmélitaines, 2).

Brown R. E., Hermeneutyka biblijna, in: R. E. Brown, J. A. Fitzmyer, R. E. Murphy (red.) Katolicki komentarz biblijny, przekł. K. Bardski, Warszawa 2001, pp. 786-1804, 1814-1817.

Catechism of the Catholic Church.

Colombàs G. M., Bibbia e monachesimo, in: G. Rocca (ed.), Dizionario degli Istituti di Perfezione, vol. I, Roma 1974, pp. I448-I458.

Colombás G. M., La Biblia en la espiritualidad del monacato primitivo, Yermo I (1963), pp. 3-20, I49-170, 27I-286.

Colombás G. M., La Biblia en la espiritualidad del monacato primitivo, Yermo 2 (I964), pp. 3-I4; II3-I29. 
Daniélou J., Écriture sainte et vie spirituelle. II. Écriture et vie spirituelle dans la Tradition. A. Époque patristique (2 $2^{e}-6^{e}$ siècle). I. Exégèse et typologie patristiques, Paris i96o, pp. 132-138 (DSp, 4, I).

Daniélou J., Origène comme exégète de la Bible, Studia Patristica I (I957), pp. 280-290.

Desprez V., Cenobityzm pachomiański, Kraków 1996 ('́ródła Monastyczne, II).

Di Berardino A., Tipologia, in: Nuovo Dizionario Patristico e di Antichità Cristiane, vol. 3 (P-Z), Genova-Milano 20o8², p. 5369-537o.

Dumont Ch., Pour un peu démythiser la "lectio" des anciens moines, Collectanea Cisterciensia 32 (1970), pp. 217-230.

Écriture sainte et vie spirituelle, Paris 1960 (DSp, 4).

Gaillard J., Écriture sainte et vie spirituelle. 6 Saint Benoit, Paris I96o, pp. I67I69 (DSp, 4).

Gargano I., L'apporto specifico del monachesimo nella lettura della Bibbia, in: La mediazione culturale del monachesimo, Parma 1987, pp. 86-95.

Goossens M., Méditation. II. Les méthodes dans la spiritualité chrétienne, Paris I980 (DSp, Io).

Gribomont J., Les Règles morales de saint Basile et le Nouveau Testament, Studia Patristica 2 (I957), pp. 416-426.

Gribomont J., Obéissance et Evangile selon saint Basile le Grand, Supplément de „La Vie Spirituelle”VI (1952), pp. I92-I95.

Guinot J. N., La typologie comme technique herméneutique: figures de l'Ancien Testament chez les Pères, Strasbourg 1989, pp. I-34 (Cahiers de Biblia Patristica, 2).

Guy J. C., Écriture sainte et vie spirituelle. 4. Le monachisme, Paris 1960, pp. 159I64 (DSp, 4).

Kirchmeyer J., Écriture sainte et vie spirituelle. $4^{\circ}$ Évagre et l'antirrhétique. $5^{\circ}$ Saint Nil, Paris 1960, pp. 164-I67 (DSp, 4).

Kurek R., Biblijna orientacja medytacji pachomińskiej, Vox Patrum 7 (I98I), pp. 247-254.

Kurek R., La meditazione della Bibbia presso i monaci pacominiani, Rivista di Vita Spirituale 37 (1983), pp. 53-67.

Le saint prophète Elie d'après les Péres de l'Église, Bellefontaine 1993 (Coll. Spiritualité Orientale, 53).

Leclercq J., Cultura umanistica e desiderio di Dio. Studio sulla letteratura monastica del Medioevo, Milano 2002.

Leclerq J., La vie parfaite, Paris I948.

Lefort L. Th., Les vies coptes de saint Pachôme et de ses premiers successeurs, Leuven 1943 . 
Leloir L., La lecture de l'Écriture selon les anciens Pères, Revue d'Ascétique et de Mystique 47 (1971), pp. 183-199.

Miquel P., Znaczenie i motywacje monastycyzmu, in: Aimé Solignac et al.; Monastycyzm. Historia i duchowość, przekł. D. Stanicka-Apostol, Kraków 2002, p. $82-83$.

Origène, Homélies sur les Nombres, ed. L. Doutreleau, Paris 1999 (SCh, 442).

Pachomiana Latina, Kraków 1996 (Źródła Monastyczne, II).

Penco G., S. Giovanni Battista nel ricordo del monachesimo medievale, Studia Monastica 3 (I96I), pp. 7-32.

Peters C., Elie et l'idéal monastique, Paris I96o, pp. 576-572 (DSp, 4, I).

Poirot É., Elie, archétype du moine. Pour un ressourcement prophétique de la vie monastique, Bellefontaine 1995 (Coll. Spiritualité Orientale, 65).

Poirot É., Les prophètes Élie et Élisée dans la littérature chrétienne ancienne, Bellefontaine 1997.

Pontifical Biblical Commission, The Interpretation of the Bible in the Church (April I5, I993).

Pope Benedict XVI, Verbum Domini.

Reguła św. Benedykta, przekł. T. M. Dąbek, Kraków 2006 (Źródła Monastyczne, 40).

Ruppert E., Meditatio-Ruminatio. Une méthode traditionelle de méditation, Collectanea Cisterciensia 39 (1977), pp. 8I-93.

Schedl N., Jesus Christus, Sein Bild bei den Mönchen der Sketis, Wien 1943.

von Severus E., Solignac A., Méditation. I. De L'Écriture aux auteurs médiévaux, Paris 1980 (DSp, ro).

Steinmann J., St Jean-Baptiste et la spiritualité du désert, Paris I955.

Vagaggini C. (ed.), Problemi e orientamenti di spiritualità monastica, Roma I96I.

Veilleux A., Holy Scripture in Pachomians Koinonia, Studia Monastica Io (1974), pp. I43-I53.

Veilleux A., Monachisme et gnose. I. Le cénobitisme pachômien et la bibliothèque copte de Nag Hammadi, Collectanea Cisterciensia 46 (I985), pp. 239-258.

de Vogüé A., La lecture quotidienne dans les monastères (300-700), Collectanea Cisterciensia 5I (1989), pp. 240-25I.

de Vogüé A., Lectiones sanctas libenter audire, Benedictina 27 (I980), pp. II-26. de Vregille B., Écriture sainte et vie spirituelle. B. Du $6^{e}$ au $12^{e}$ siècle. I. Saint Grégoire le Grand, Paris I96o, pp. I69-I76 (DSp, 4). 